\title{
KONSEP KHILAFFAH DAN KESALEHAN LINGKUNGAN DALAM TRADISI ISLAM
}

\author{
Joko Christanto \\ Universitas Gadjah Mada (UGM) Yogyakarta \\ Jl. Bulaksumur (+62-274)-64919336 Yogyakarta 55281 \\ E-mail: joko_yogya@yahoo.com \\ HP. +62-81392775077
}

Abstract: This article describes and reveals the concept of khalifah in Islam as the basic in natural exploration. This concept brings man into the highest degree among God' creatures. Man's responsibility is as the God's representative in the earth. Man should be inspired by some of God's name such as arranger (mudabbir), protector (hăfidz), and educator (murabbi). The data are collected and documented from the main source; al-Qur'an and al-Sunnah and it is analyzed with bayani and philosophical approach. This article shows that khalifah concept in Islam is based on ilähiyyah and darüriyyah (need) insāniyyah transcendence. The environmental damage is caused by the unbalanced situation, man just focuses on the second point.

Abstrak: Tulisan ini mendeskripsikan dan mengurai tentang konsep khalifah dalam Islam sebagai dasar yang paling asasi dalam mengelola alam. Konsep ini mengantarkan pada keluhuran derajat manusia dibanding makhluk lain. Di antara tugas khalifah adalah menjadi wakil Allah di muka bumi. Di antara sifat Allah adalah pengatur (mudabbir), pemelihara (hāāiz), mendidik (murabbi), dan seterusnya. Data-data dikumpulkan dengan dokumtasi dari sumber utama Islam al-Qur'an dan al-Sunah. Data-data yang telah terkumpul dianalisis dengan pendekatan bayani (tafsir) dan filosofis. Artikel ini menunjukkan bahwa konsep khalifah dalam Islam berakar pada transendensi ilāhiyyah dan đ̣arūriyyah (kebutuhan) insāniyyah. Kerusakan lingkungan muncul karena ketidakseimbangan kedua hal di atas. Manusia belum dapat memerankan transendensi ilahiyah dan masih cenderung memenangkan aspek yang kedua.

Kata Kunci: Khalifah, Manusia, Allah, Islam, Lingkungan Hidup. 


\section{A. Pendahuluan}

Meningkatnya jumlah penduduk pada suatu wilayah memberikan pengaruh terhadap tingkat tekanan penduduk terhadap lingkungan. Pelestarian alam dan lingkungan hidup ini tidak terlepas dari peran manusia, sebagai khalifah di muka bumi, sebagaimana yang disebut dalam Q.S.2:30, "Dan (ingatlah) ketika Tuhanmu berfirman kepada para malaikat, "Aku hendak menjadikan khalifah di bumi."

Sebagai khalifah, manusia diberi kedudukan oleh Allah SWT untuk mengelola suatu wilayah. Dia berkewajiban untuk menciptakan suatu masyarakat beserta tatanan yang baik yang sesuai dengan Allah SWT, yakni kehidupan masyarakatnya harmonis, agama, akal, dan budayanya terpelihara. Surat alRaḥmān, ayat 1-12, adalah ayat yang luar biasa indah untuk menggambarkan penciptaan alam semesta dan tugas manusia sebagai khalifah di muka bumi ini. Bahkan, ayat ini ditafsirkan secara lebih spesifik oleh Nasr, dosen studi Islam di George Washington University, Amerika Serikat dalam dua bukunya "Man and Nature (1990)" dan "Religion and the Environmental Crisis (1993)" dalam fithab.multiply.com, 2008, sebagai berikut:

"......Man therefore occupies a particular position in this world. He is at the axis and centre of the cosmic milieu at once the master and custodian of nature. By being taught the names of all things he gains domination over them, but he is given this power only because he is the vicegerent (khalifah) of God on earth and the instrument of His Will. Man is given the right to dominate over nature only by virtue of his theomorphic make up, not as a rebel against heaven."

Dari kutipan tersebut, tugas manusia di muka bumi ini sebagai khalifah (pemimpin) dan sebagai wakil Allah dalam memelihara bumi (mengelola lingkungan hidup). Belakangan ini, manusia di muka bumi hanya hidup dalam gelamor yang jauh dari sendi-sendi agama sehingga lalai dengan tugasnya sebagai khalifah. Tulisan ini bermaksud untuk mengkaji dan mengurai konsep khalifah dan perannya dalam perbaikan lingkungan hidup.

\section{B. KONSEP KHILĀFAH}

Dalam konsep khilāfah, manusia telah dipilih oleh Allah SWT sebagaimana Q.S.2:30 sebagai khalifah di muka bumi ini (khalifatullāh fi al-arộ). Al-Ṭabari (2000: 448) menjelaskan bahwa khalifah berarti mustakhlif (pengganti, wakil). Sementara Ibn Ishạa dalam al-Ṭabarī (2000: 499) memaknainya dengan pemakmur, pembuat ketenangan. Konsep di atas senada dengan al-Qurțubi (TT: 263) yang mengatakan bahwa khalifah berarti pengganti sebelumnya yang telah 
ada. Khalifatullah berarti imọ̄i ạ̣kāmillāh wa awāmirihi (menunaikan dan melaksanakan hukum-hukum Allah). Adapun al-Baghawì (1997: 29) menjelaskan bahwa khalifah berarti menjadi badal (wakil), maknanya bahwa Adam AS menjadi badal (wakil) sekaligus menggantikan wakil sebelumnya yakni jin. Dia menjadi wakil di bumi-Nya untuk melaksanakan hukum-hukumnya (alBaghawi, 1997: 29).

Konsekuensi sebagai wakil Allah, manusia wajib untuk bisa merepresentasikan dirinya sesuai dengan sifat-sifat Allah. Salah satu sifat Allah SWT tentang alam adalah sebagai pemelihara dan atau penjaga alam (rabb al'ālamīn). Sebagai wakil (khalīfah) Allah SWT di muka bumi, manusia harus aktif dan bertanggung jawab untuk menjaga bumi. Artinya, manusia diberi tugas menjaga keberlangsungan fungsi bumi sebagai tempat kehidupan makhluk Allah SWT termasuk manusia dan sekaligus menjaga keberlanjutan kehidupannya. Manusia mempunyai hak (diperbolehkan) untuk memanfaatkan apa yang ada di muka bumi (sumberdaya alam) dengan tidak melampaui batas at au berlebihan (lihat al-Alūsi, T.T.: 256). Dalam Q.S.6:141-142, Allah berfirman yang artinya:

"Dan dialah yang menjadikan kebun-kebun yang berjunjung dan yang tidak berjunjung, pohon korma, tanam-tanaman yang bermacam-macam buahnya, zaitun dan delima yang serupa (bentuk dan warnanya) dan tidak sama (rasanya), makanlah dari buahnya (yang bermacam-macam itu) bila dia berbuah, maka tunaikanlah haknya di hari memetik hasilnya (dengan disedekahkan kepada fakir miskin); dan janganlah kamu berlebih-lebihan. Sesungguhnya Allah tidak menyukai orang yang berlebih-lebihan."

Manusia diperbolehkan untuk memanfaatkan semua sumberdaya yang ada di alam semesta ini dengan bijak dan atau tidak melampaui batas, eksploitasi yang dilakukan tidak mengakibatkan langka dan punahnya spisies tertentu serta pemanfaatannya tidak mengganggu terhadap keseimbangan alam dan menimbulkan kerusakan alam. Manusia memiliki kewajiban melestarikan alam semesta dan lingkungan hidup dengan sebaik-baiknya. Hal itu bertujuan agar hidup di dunia menjadi makmur sejahtera penuh keberkahan dan menjadi bekal di hari akhir kelak. Manusia diberi amanah untuk membuat kebaikan di muka bumi. Tanggung jawab mengelola dunia sama pentingnya dengan akhirat. Hal ini secara langsung diungkapkan oleh Allah dalam salah satu firman-Nya dalam surat Q.S.7: 56:

"Dan janganlah kamu membuat kerusakan di muka bumi, sesudah (Allah) memperbaikinya dan berdoalah kepada-Nya dengan rasa takut (Tidak akan diterima) dan harapan (akan dikabulkan). Sesungguhnya rahmat Allah amat dekat kepada orang-orang yang berbuat baik. 
Dalam surat Q.S.30:41, manusia telah diingatkan bahwa kerusakan muka bumi, baik di laut maupun darat, merupakan akibat ulah tangan manusia. Ayatayat al-Qur'an di atas menuntut konsekuensi logis, yaitu perlunya kesatuan pikiran, sikap dan perbuatan dalam posisi manusia sebagai khalifah. Hal itu berarti amaliah manusia duniawi dan ukhrawi sebagai satu kesatuan yang tak dapat dipisahkan. Hal yang tak kalah pentingnya adalah harus mampu untuk menekankan pada "kesalehan lingkungan", yang didasarkan pada akhlak dan perilaku yang santun dalam menjaga dan melestarikan lingkungan, dan memaknainya sebagai bentuk ibadah dan perwujudan syukur kepada Sang Khālik." Tidak ada satu pun di antara manusia yang dapat menghitung berapa nikmat Allah SWT yang dianugerahkan kepada manusia, sebagaimana Q.S.14: 34, “Jika kamu menghitung nikmat Allah, niscaya kamu tidak akan sanggup menghitungnya." dan Q.S.31:20 “Dan Dia menyempurnakan nikmat-Nya kepadamu lahir dan batin.” (Q.S.31:20).”Maka nikmat Rabb kamu yang manakah yang kamu dustakan?" (Q.S.55:13).

Peradaban cenderung menempatkan manusia sebagai porosnya (antroposentris) hingga seringkali berakibat pada pemberhalaan hawa nafsu dalam memenuhi keinginannya yang pada gilirannya dapat menimbulkan kerusakan lingkungan. Manusia perlu melihat kembali kedudukan dan martabatnya sebagai khalīfatullāh fi al-arḍ. Kesadaran manusia dalam perannya sebagai khalifah di muka bumi seyogyanya menjadikan manusia bertindak arif dan bijaksana dalam mengelola kekayaan alam dan bumi sehingga terhindar dari kerusakan.

\section{Pendekatan Solutif Mengatasi Krisis Lingkungan}

Secara garis besar, terdapat dua pendekatan yang digunakan sebagai solusi untuk mengatasi krisis lingkungan baik secara individual maupun sosial. Pertama, pemecahan krisis melalui pertimbangan atas segala sesuatu yang langsung terlihat, situasi yang sedang berlangsung, membuat perubahan jangka pendek dan membuat suatu perencanaan ulang. Kedua, pemecahan krisis melalui penjabaran sebab dan faktor yang mendorong munculnya krisis (aspek ontologis), melalui dasar keilmuan (aspek epistemologis), kerangka ruhani, dan intelektual, serta paradigma budaya yang menyebabkan krisis tersebut terjadi dengan tetap mengacu kepada pendekatan pertama. Pendekatan kedua merupakan solusi yang memberikan pengaruh lebih nyata. Jika hanya berpegang pada pendekatan pertama, maka masalah akan muncul kembali dan menjadi lebih serius karena krisis sebelumnya masih aktif. 
Beberapa percobaan penting telah dilakukan terkait dengan beberapa pendekat an tersebut. Hal itu misalnya proyek penggantian kelengkapan transportasi, membuat bahan bakar non-fosil, merancang teknologi ramah lingkungan, pendekat an pertama tidaklah dapat menghapus krisis lingkungan dan tidak dapat menjadi solusi yang memadai bagi masalah tersebut. Penyebab munculnya krisis lingkungan (penyebab eksistensi dan kognisi) harus diketahui sebelum manusia dapat mengatasi masalah tersebut. Dugaan penyebab kerusakan, kehancuran, dan krisis dalam lingkungan adalah perspektif mengenai manusia dan alam semesta pada era modern. Hal itu menjadi pandangan-dunia yang merupakan imitasi mutlak saintisme. Perspektif tersebut mengabaikan semua unsur filosofi, budaya, dan kerangka spiritual; mengurangi tingkat kebenaran dan membatasi ruang lingkup kognisi (pengenalan) manusia dan tingkat eksistensi hanya kepada sains sensasional dan segala sesuatu yang bersifat material. Perspektif tersebut secara perlahan menghilangkan kehidupan jiwa, tujuan, harapan, kebahagiaan, dan kesucian dengan cara pemutusan materi alamiah dari jiwa, dari dunia gaib, dan dari kemurnian mutlak dan kebenaran konstan pembentuk filosofi keagungan.

“....barang siapa di antara orang Islam yang menanam tanaman maka hasilnya yang dimakan akan menjadi sedekahnya, dan hasil tanaman yang dicuri akan menjadi sedekah. Dan tidaklah seseorang pun mendermakan tanamannya, maka akan menjadi sedekahnya sampai hari kiamat (HR Muslim).

Rasulullah melarang menggunakan air wudhu secara boros, dilarang kencing pada air yang tidak mengalir, kerusakan alam ini disebabkan ulah tangan manusia, mubazir adalah teman setan. Kalau besok mau kiamat dan Anda mempunyai sebuah biji tanaman, maka tanamlah.

Banyak dijumpai ayat-ayat ilmiah dalam al-Qur'an yang membahas tentang lingkungan yang memberikan pesan-pesan mengenai lingkungan dengan sangat jelas dan prospektif. Di dalamnya memberikan penjelasan tentang lingkungan sebagai suatu sistem, tanggung jawab manusia untuk memelihara lingkungan hidup, larangan merusak lingkungan, sumberdaya vital dan problematikanya, peringatan mengenai kerusakan lingkungan hidup yang terjadi karena ulah tangan manusia, dan pengelolaan yang mengabaikan petunjuk Allah serta solusi pengelolaan lingkungan.

\section{Pembangunan Lingkungan Hidup}

Lingkungan hidup sebagai sumberdaya yang dapat dimanfaatkan manusia guna memenuhi kebutuhan hidupnya. Allah SWT berfirman: "Dialah yang menjadikan bumi itu mudah bagi kamu, maka berjalanlah di segala penjurunya, 
dan makanlah sebagian dari rizki-Nya. Dan hanya kepada-Nya lah kamu (kembali setelah) dibangkitkan.”(Q.S.67:15). Lingkungan hidup sebagai sumberdaya mempunyai regenerasi dan asimilasi yang terbatas. Selama eksploitasi atau penggunaannya di bawah batas daya regenerasi atau asimilasi, maka sumberdaya terbaharui dapat digunakan secara lestari. Akan tetapi, apabila batas itu dilampaui, maka sumberdaya akan mengalami kerusakan dan fungsinya sebagai faktor produksi dan konsumsi atau sarana pelayanan akan mengalami gangguan.

Pembangunan lingkungan hidup untuk pengubahan lingkungan hidup, yakni mengurangi risiko lingkungan dan at au memperbesar manfaat lingkungan. Manusia mempunyai tanggung jawab untuk memelihara dan memakmurkan alam sekitarnya. Allah SWT berfirman:

"Dan kepada Tsamud (Kami utus) saudara mereka Shālih. Shālih berkata: "Hai kaumku, sembahlah Allah, sekali-kali tidak ada bagimu Tuhan selain Dia. Dia telah menciptakan kamu dari bumi (tanah) dan menjadikan kamu pemakmurnya, karena itu mohonlah ampunan-Nya, kemudian bertobatlah kepada-Nya. Sesungguhnya Tuhanku amat dekat (rahmat-Nya) dan lagi memperkenankan (do’a hamba-Nya)."(Q.S.11:61).

Upaya pemeliharaan dan pemakmuran dari ayat tersebut, bertujuan untuk melestarikan sumberdaya alam dan mempertahankan daya dukung lingkungan sehingga dapat menopang secara berkelanjutan terhadap pertumbuhan dan perkembangan serta pemanfaatannya yang diusahakan dalam pembangunan. Dalam konteks ini, lingkungan berubah, tetapi harus tetap dipertahankan pada kondisi yang mampu untuk menopang secara berkesinambungan pertumbuhan dan perkembangannya. Karena itu, hal itu dapat terjaminnya kelangsungan hidup generasi sekarang dan generasi yang akan datang. Pandangan tersebut dapat dicapai apabila manusia tidak membuat kerusakan di bumi. Allah SWT berfirman:

"Dan janganlah kamu membuat kerusakan di muka bumi, sesudah (Allah) memperbaikinya dan berdo'alah kepada-Nya dengan rasa takut dan harapan. Sesungguhnya Allah amat dekat kepada orang yang berbuat baik.' (Q.S.7:56).

Berkaitan dengan pemeliharaan lingkungan, Rasulullah SAW mengajarkan kepada manusia tentang beberapa hal, yakni agar melakukan penghijauan, melestarikan kekayaan hewani dan hayati, dan lain sebagainya. Pandanganpandangan Rasulullah SAW dapat dilihat pada kutipan berikut ini.

"Barang siapa yang memotong pohon Sidrah, maka Allah akan meluruskan kepalanya tepat ke dalam neraka."(HR. Abu Daud dalam Sunahnya). 
"Barang siapa di antara orang Islam yang menanam tanaman, maka hasil tanamannya yang dimakan akan menjadi sedekahnya, dan hasil tanaman yang dicuri akan menjadi sedekah. Dan barang siapa yang merusak tanamannya, maka akan menjadi sedekahnya sampai hari Kiamat."(HR. Muslim).

"Setiap orang yang membunuh burung pipit atau binatang yang lebih besar dari burung pipit tanpa ada kepentingan yang jelas, dia akan dimintai pertanggungjawabannya oleh Allah." Ditanyakan kepada Nabi: "Wahai Rasulullah, apa kepentingan itu?" Rasulullah menjawab: "Apabila burung itu disembelih untuk dimakan, dan tidak memotong kepalanya kemudian dilempar begitu saja."

Beberapa pandangan tersebut menunjukkan bahwa sebenarnya Islam melalui al Qur'an dan Sunah Rasulullah SAW telah diajarkan mengenai konsep dan aplikasinya tentang berlaku santun dalam pengelolaan lingkungan hidup dan berbagai komponennya lengkap dengan konsekuensi masing-masing tindakan yang dilakukan oleh manusia terhadap alam beserta isinya.

\section{E. Sumberdaya Lahan dan Tanah}

Manusia berasal dari tanah dan hidup dari dan di atas tanah. Hubungan antara manusia dan tanah sangat erat. Kelangsungan hidup manusia di antaranya tergantung pada tanah, dan sebaliknya tanah pun memerlukan perlindungan manusia untuk eksistensinya sebagai tanah yang memiliki fungsi. Allah SWT berfirman:

"Dan apakah mereka tidak memperhatikan bumi, berapakah banyaknya Kami tumbuhkan di bumi itu pelbagai macam tumbuhan-tumbuhan yang baik? Sesungguhnya pada yang demikian itu benar-benar terdapat suatu tanda kekuasaan Allah. Dan kebanyakan mereka tidak beriman"(Q.S.26:7-8).

Dengan lahan itu, manusia bisa membuat tempat tinggal, bercocok tanam, dan melakukan aktivitas lainnya. Pemandangan ironis di Indonesia terlihat cukup mencolok di antaranya adalah penebangan hutan untuk ekspor dan alasan lain yang sering tidak masuk akal dan mengingkari kaidah keberlanjutan (tanpa diikuti upaya peremajaan yang memadai) dan perluasan kota yang melebar, mengokupasi tanah-tanah subur perdesaan. Polis berkembang menjadi metropolis untuk kemudian membengkak menjadi megapolis (beberapa kota besar luluh jadi satu) dan Ecumenopolis (negara kota). Akhirnya, salah satu nanti akan menjadi Necropolis (kota mayat). Penebangan hutan tanpa diikuti peremajaan kembali menyebabkan rusaknya tanah perbukitan sehingga terjadi bencana tanah longsor, banjir bandang dan dampak bencana ikutannya. Apalagi adanya kebakaran hutan di Indonesia semakin menyebabkan rusaknya ekologi hutan. Padahal, keberadaan hutan sangat berguna bagi keseimbangan hidro- 
logik, hidro-orologik dan klimatologik, termasuk sebagai tempat berlindungnya binatang dan terjaganya biodiversitas.

Perencanaan tata ruang yang kurang baik akan berdampak negatif yang luar biasa. Pembangunan kota dan perumahan menyebabkan semakin sempitnya lahan pertanian yang subur. Selain itu, terjadi kerusakan tingkat kesuburan tanah yang disebabkan pemakaian teknologi kimiawi yang melewati ambang batas. Pemakaian pupuk kimiawi yang berlebihan tersebut merusak ekosistem pertanian, di antaranya semakin resistensi dan resurjensinya hama dan penyakit tanaman. Hasil produksi pertanian menurun yang akhirnya berdampak pada kehidupan sosial-ekonomi penduduk. Berdasarkan pada kenyataan tersebut, mestinya perkara konservasi tanah dan lahan sudah merupakan suatu keharusan dalam rangka mempertahankan berlangsungnya kehidupan manusia. Usaha yang dapat dilakukan antara lain adalah dengan melakukan reboisasi, perencanaan tata ruang yang baik (lahan subur untuk pertanian dan lahan tandus untuk industri atau bangunan), dan penerapan sistem pertanian yang ramah lingkungan (pertanian organik atau lestari).

\section{F. Sumberdaya Air}

Manusia membutuhkan air untuk hidup karena dua pertiga tubuh manusia terdiri dari air. Allah SWT berfirman, "Dan Kami beri minum kamu dengan air tawar?"(Q.S.77:27). Tanpa air, seluruh gerak kehidupan akan terhenti karena kekeringan. Hal itu sebenarnya telah ditunjukkan oleh alam dalam bentuk siklus hidrologis dari air yang berlangsung terus-menerus. Volume air yang dikandungnya tetap, hanya bentuknya yang berubah. Allah SWT berfirman, "Demi langit yang mengandung hujan (raj'i)" (Q.S.86:11). Kata Raj'i berarti "kembali". Hujan dinamakan raj'i dalam ayat ini karena hujan itu berasal dari uap air yang naik dari bumi (baik dari air laut, danau, sungai dan lainnya) ke udara, kemudian turun ke bumi sebagai hujan, kemudian kembali ke atas, dan dari at as kembali ke bumi dan begitulah seterusnya (siklus hidrologi).

Kadang-kadang, manusia melakukan sesuatu yang menyebabkan terhambatnya siklus hidrologi tersebut. Sebagai contoh: membuat saluran drainase dengan lapisan semen yang kedap air dan mengecor jalan dengan semen, sehingga air mengalir cepat ke laut dan mengingkari fungsinya sebagai pemberi kehidupan (life giving role). Sungai-sungai yang dulu sebagai organisme yang mampu memamah biak benda-benda yang dibuang ke dalamnya dan memberikan pasokan air bersih yang memadai untuk kehidupan. Sekarang ini, sungai-sungai tersebut lebih berwujud berupa tempat pembuangan sampah yang terbuka, dijejali dengan limbah industri dan buangan rumah tangga yang 
tidak mungkin lagi atau tidak mudah dicerna guna menghasilkan air yang sedikit bersih sekalipun. Kerusakan lingkungan pada ekosistem pantai yakni rusaknya hut an bakau (mangrove) di tepi pantai, dan rusaknya terumbu karang. Padahal, hutan bakau dan terumbu karang sangat berfungsi bagi keseimbangan dan keberlangsungan ekosistem pesisir dan lautan, rantai makanan, melindungi abrasi laut dan keberlanjutan sumberdaya lautan.

\section{G. Sumberdaya Udara}

Tanpa udara bersih, manusia takkan diperoleh kehidupan sehat. Setiap hari, rata-rata manusia menarik napas 26.000 kali berkisar antara 18 sampai 22 kali setiap menitnya. Pentingnya udara sering diabaikan terutama karena sampai kini manusia masih bisa memperolehnya tanpa harus mengeluarkan biaya. Padahal, di Tokyo saat ini mulai dijual udara bersih (oksigen) dalam tabung. Suatu kejutan pertama yang menyadarkan manusia akan bahaya udara kotor terjadi di Inggris pada tahun 1952 yang dikenal dengan "The Great London Smog" yang menyebabkan sekitar 4000 jiwa melayang dan sejumlah besar penduduk menderita penyakit bronkitis, jantung, dan berbagai penyakit pernapasan lainnya. Bahkan bangunan, lukisan, patung, atau monumen pun hancur karena asap dan gas mobil. Kasus di Yogyakarta, konsumsi tertinggi dari kendaraan bermotor (konsumsi bahan bakar solar dan bensin mencapai 170.000 liter pada tahun 1990-1991) dan kedua bahan bakar rumah tangga (rata-rata 84.000 liter). Hal itu menyebabkan $\mathrm{CO}_{2}$ dan timbal $(\mathrm{Pb})$ melewati ambang batas yang diperkenankan.

Di Jakarta, dari kendaraan umum, 765.000 at au 60\% mengeluarkan gas buang diatas ambang batas baku mutu. Artinya, setiap menit selalu keluar kandungan racun dari knalpot mobil itu, sulfur oksida, nitrogen oksida, dan timbal $(\mathrm{Pb})$. Konsentrasi timbal di udara mencapai 1,7-3,5 mirogram per meterkubik dan pada 2005 mencapai 1,8-3,6 mikrogram per meterkubik. Padahal, jumlah kendaraan roda empat di Jakarta mencapai 9,1 juta (1.274.000 berstat us kendaraan umum). Upaya yang bisa ditempuh antara lain: memperluas kawasan hijau (hutan kota), pemakaian bahan bakar akrab lingkungan (BBL), knalpot dipasang filter, dan mengurangi pemakaian kendaraan pribadi.

\section{H. Kerusakan Lingkungan}

Manusia telah diperingatkan Allah SWT dan Rasul-Nya agar jangan melakukan kerusakan di bumi, tetapi manusia mengingkarinya. Allah SWT berfirman: "Dan bila dikatakan kepada mereka: "Janganlah membuat kerusakan di muka bumi", mereka menjawab: "Sesungguhnya kami orang-orang yang 
mengadakan perbaikan." (Q.S.2:11). Keingkaran mereka disebabkan karena keserakahan mereka dan mereka mengingkari petunjuk Allah SWT dalam mengelola bumi ini sehingga terjadilah bencana alam dan kerusakan di bumi karena ulah tangan manusia. Allah SWT berfirman:

"Telah tampak kerusakan di darat dan di laut disebabkan karena perbuatan tangan manusia, supaya Allah merasakan kepada mereka sebagian dari (akibat) perbuatan mereka, agar mereka kembali (ke jalan yang benar)". Katakanlah: "Adakan perjalanan di muka bumi dan perhatikanlah bagaimana kesudahan orang-orang dahulu. Kebanyakan dari mereka itu adalah orangorang yang mempersekutukan (Allah)"(Q.S.30: 41-42).

Di samping adanya problematika ketiga sumber daya vital di atas, Otto Soemarwoto membagi kerusakan lingkungan yang mengancam kehidupan bumi menjadi dua, yaitu kerusakan yang bersifat regional (seperti hujan asam) dan yang bersifat global (seperti pemanasan global, kepunahan jenis, dan kerusakan lapisan ozon di stratosfer). Hujan asam disebabkan oleh pencemaran udara yang berasal dari pembakaran bahan bakar fosil, yaitu gas bumi, minyak bumi, dan batu bara. Pembakaran itu menghasilkan gas oksida belerang dan oksida nitrogen. Kedua jenis itu dalam udara mengalami reaksi kimia dan berubah menjadi asam (berturut-turut menjadi asam sulfat dan asam nitrat). Asam yang langsung mengenai bumi disebut deposisi kering, dan asam yang terbawa hujan yang turun ke bumi disebut deposisi basah. Keduanya disebut hujan asam. Hujan asam menyebabkan kematian organisme air sungai dan danau serta kerusakan hutan dan bangunan.

Pemanasan global (global warming) adalah peristiwa naiknya intensitas efek rumah kaca (ERK) yang terjadi karena adanya gas dalam atmosfer yang menyerap sinar panas (sinar inframerah) yang dipancarkan bumi. Gas itu disebut gas rumah kaca (GRK). Dengan penyerapan itu, sinar panas terperangkap sehingga naiklah suhu permukaan bumi. Seandainya tidak ada GRK dan karena itu tidak ada ERK, suhu permukaan bumi rata-rata hanya $-18^{\circ} \mathrm{C}$ saja, terlalu dingin bagi kehidupan makhluk. Dengan adanya ERK, suhu bumi adalah rata-rata $15^{\circ} \mathrm{C}$ sehingga ERK sangat berguna bagi kehidupan di bumi. Akan tetapi, akhir-akhir ini semakin naiknya kadar GRK dalam atmosfer, yaitu $\mathrm{CO}_{2}$ dan beberapa gas lain (seperti $\mathrm{CO}_{2}, \mathrm{CH}_{4}$, dan $\mathrm{N}_{2} \mathrm{O}$ ) menyebabkan naiknya intensitas ERK sehingga suhu permukaan bumi akan naik pula. Inilah yang disebut global warming. Berbagai dampak negatif pemanasan global, yaitu menyebabkan perubahan iklim sedunia (perubahan curah hujan), naiknya frekuensi maupun intensitas badai (seperti di Bangladesh dan Filipina semakin menderita), bertambahnya volume air laut, dan melelehnya es abadi di 
pegunungan dan kutub. Hal itu juga menyebabkan keringnya tanah dan kekeringan yang berdampak negatif terhadap pertanian dan perikanan. Bertambahnya volume air laut, maka permukaan laut akan naik. Dengan laju kenaikan kadar GRK seperti sekarang diperkirakan pada sekitar 2030 suhu akan naik $1,5-4,5^{\circ} \mathrm{C}$. Kenaikan suhu ini menyebabkan naiknya permukaan laut 25 $140 \mathrm{~cm}$.

Dampak naiknya permukaan laut adalah tergenangnya daerah pantai, tambak, sawah, dan kota yang rendah seperti Jakarta, Surabaya, dan Semarang serta beberapa pulau di Indonesia. Kenaikan permukaan laut juga menyebabkan laju erosi pantai. Untuk kenaikan permukaan laut $1 \mathrm{~cm}$, garis pantai akan mundur $1 \mathrm{~m}$, sehingga kenaikan permukaan laut $25-140 \mathrm{~cm}$, garis pantai mundur 25-140 m. Kepunahan jenis berarti hilangnya sumberdaya gen yang mengurangi kemampuan manusia dalam pembangunan pertanian, perikanan, peternakan, dan kehutanan. Penyebabnya antara lain karena adanya hujan asam dan penyusutan luas hutan, serta penggunaan sistem monokultur atau varietas unggul sehingga varietas lokal hilang, seperti varietas padi lokal yang hampir sirna.

Ozon ialah senyawa kimia yang terdiri atas tiga atom oksigen. Di lapisan atmosfer yang rendah, ia mengganggu kesehat an dan di lapisan atas atmosfer ia melindungi makhluk hidup dari sinar ultraviolet yang dipancarkan matahari. Apabila kadar ozon di stratosfer berkurang, kadar sinar ultraviolet yang sampai ke bumi bertambah. Oleh karena itu, risiko untuk mengidap penyakit kanker kulit, katarak, dan menurunnya kekebalan tubuh akan meningkat. Penurunan kadar ozon disebabkan karena rusaknya ozon oleh segolongan zat kimia yang disebut chlorofluorocarbon (CFC) yang banyak digunakan dalam industri dan kehidupan, seperti gas freon (pendingin AC dan almari es), gas pendorong dalam aerosol (parfum, hairspray, dan zat racun hama) dan lainnya. Bila manusia tetap saja berkeras kepala menjejalkan gas rumah kaca ke atmosfer, sebelum akhir abad mendatang pasti akan terjadi perubahan iklim yang tak terduga, banyak angin ribut dan angin topan, air laut meredam pulau-pulau berdataran rendah, di samping munculnya padang pasir baru karena bumi yang makin panas.

Upaya nyata yang perlu dilakukan untuk menghindari bencana itu antara lain dengan menggunakan energi secara efisien, mengembangkan sumber energi baru dan aman, mencegah terjadinya kebakaran dan penggundulan hutan atau penebangan pohon secara besar-besaran, menanam pepohonan baru, dan menggalakan penggunaan transportasi umum. Kampanye besar-besaran untuk mengurangi penggunaan traktor, diesel, lemari es, kaleng semprot, AC, dan lainlain. Langkah ini mudah diucapkan tapi sulit dilaksanakan. Hal itu tetap harus 
dilakukan, seperti yang dicetuskan oleh Gurmit Singh: "Global warning on global warming demands global action”. Peringatan global terhadap pemanasan global menuntut adanya tindakan global.

\section{Solusi PengelolaAn LingKungan}

Proses kerusakan lingkungan berjalan secara progresif dan membuat lingkungan tidak nyaman bagi manusia, bahkan jika terus berjalan akan dapat membuatnya tidak sesuai lagi untuk kehidupan. Itu semua karena ulah tangan manusia sendiri sehingga bencananya juga akan menimpa manusia itu sendiri (Q.S.30:41-42). Untuk mengatasi masalah tersebut, pendekatan yang dapat manusia lakukan di antaranya dengan pengembangan sumberdaya manusia yang handal, pembangunan lingkungan berkelanjutan, dan kembali kepada petunjuk Allah SWT dan Rasul-Nya dalam pengelolaan lingkungan hidup. Adapun syarat SDM handal antara lain sadar akan lingkungan dan berpandangan holistis, sadar hukum, dan mempunyai komitmen terhadap lingkungan.

Ajaran tentang hidup serasi dengan alam sekitar, dengan sesama manusia, dan dengan Allah SWT telah diajarkan kepada manusia. Allah berfirman: "Dan tiadalah Kami mengutus kamu, melainkan untuk (menjadi) rahmatan lil'alamiin" (Q.S.21: 107). Pandangan hidup ini mencerminkan pandangan yang holistis terhadap kehidupan, yaitu bahwa manusia adalah bagian dari lingkungan tempat hidupnya. Dalam pandangan ini, sistem sosial manusia bersama dengan sistem biogeofisik membentuk satu kesatuan yang disebut ekosistem sosiobiogeofisik sehingga manusia menjadi bagian dari ekosistem tempat hidupnya dan bukannya hidup di luarnya. Oleh karenanya, keselamatan dan kesejahteraan manusia tergant ung dari keutuhan ekosistem tempat hidupnya. Jika terjadi kerusakan pada ekosistemnya, maka manusia akan menderita. Biogeofisik merupakan sumberdaya bagi manusia, namun pemanfaatannya untuk kebutuhan hidupnya dilakukan dengan hati-hati agar tidak terjadi kerusakan pada ekosistem. Dengan begitu, manusia akan sadar terhadap hukum yang mengatur lingkungan hidup dari Allah SWT dan komitmen terhadap masalah-masalah lingkungan hidup.

Salah satu prinsip filsafat lingkungan hidup Islam adalah alam semesta diciptakan berdasarkan keseimbangan dan harmoni antar anggota alam tersebut. Manusia harus berusaha maksimal untuk menjaga keseimbangan dan berinteraksi secara benar dengan maujud-maujud lain di alam. Tentang keseimbangan dan harmoni alam semesta, Allah berfirman: "Kamu sekali-kali tidak melihat pada ciptaan Tuhan Yang Maha Pengasih sesuatu yang tidak 
seimbang"(Q.S.67: 13). Segala sesuatu tercipta berdasarkan perhitungan dan ukuran dan ditempatkan di posisi yang tepat: "Dan Dia telah menciptakan segala sesuatu dan Dia menetapkan ukuran-ukurannya dengan serapihrapihnya" (Q.S.25:2) "Segala sesuatu pada sisi-Nya ada ukurannya", "Matahari dan bulan (beredar) menurut perhitungan, bintang dan pohon tunduk kepadaNya, Allah meninggikan langit dan Dia meletakkan neraca" (Q.S.55:5) "Ciptaan Tuhan Yang telah mengokohkan segala sesuatu" (Q.S.27:8) Tidak satupun benda tercipta sia-sia: "dan mereka memikirkan tentang penciptaan langit dan bumi.. Ya Tuhan Kami tiadalah Engkau menciptakan ini dengan siasia, Maha Suci Engkau" (Q.S.3:191). Metode penciptaan terbaik telah digunakan Oleh Tuhan: "Yang membuat segala sesuatu yang Dia ciptakan sebaikbaiknya”(Q.S.32:7) Kehidupan segala sesuatu tergantung pada air menurut alQur'an "Dan Kami Jadikan dari air segala sesuatu yang hidup" (Q.S.21:30). Air telah diciptakan sesuai takaran khusus: "Dan Kami turunkan air dari langit menurut suatu ukuran lalu kami jadikan air itu menetap di bumi dan sesungguhnya Kami benar-benar berkuasa menghilangkannya" (Q.S.32:1). Relasi dan kuantitas segala sesuatu telah ditentukan dengan sangat teliti: "Dan Kami telah menghamparkan bumi dan menjadikan padanya gunung-gunung dan Kami tumbuhkan padanya segala sesuatu menurut ukuran" (Q.S.15:19).

Tent ang harmoni antara angin, air, dan tumbuh-tumbuhan, Allah berfirman:

"Dan Dialah yang mengirim angin sebagai pembawa berita gembira sebelum kedatangan rahmat-Nya, hingga apabila angin itu membawa awan mendung, Kami halau ke suatu daerah yang tandus, lalu Kami turunkan hujan di daerah itu, maka Kami keluarkan dengan sebab hujan itu beragam buah-buahan" (Q.S.7:57).

Adapun tentang keserasian antara bumi, langit, air dan manusia, Allah berfirman:

"Dialah Yang menjadikan bumi sebagai hamparan bagimu dan langit sebagai atap" (Q.S.2:22)

"Bukankah Kami telah jadikan bumi sebagai hamparan”(Q.S.78:6)

"Dan bumi sesudah itu dihamparkannya. Dia memancarkan darinya mata air dan tetumbuhan. Dan gunung-gunung dipancangkan-Nya dengan teguh untuk kesenangan kalian dan ternak kalian"(Q.S.79:30-33).

Jika manusia menjaga keseimbangan ini dan tidak merusaknya, ia telah memaksimalkan keuntungannya dari alam karena sejak semula alam diciptakan untuk digunakan manusia. 
"Dialah Allah yang menjadikan segala yang ada di bumi untuk kalian" (Q.S.2:29) "Tidakkah kalian perhatikan sesungguhnya Allah menundukkan untuk kalian apa yang di langit dan apa yang di bumi dan telah menyempurnakan untuk kalian nikmat-Nya lahir dan batin" (Q.S.31:20)

"Dan Dialah Allah yang menundukkan lautan untuk kalian, agar kalian dapat memakan darinya daging yang segar, dan kalian mengeluarkan dari lautan itu perhiasan yang kamu pakai dan engkau melihat bahtera berlayar padanya dan agar kalian mencari dari karunia-Nya dan agar kalian bersyukur"(Q.S.16:14). "Allah lah yang telah menciptakan langit dan bumi dan menurunkan air dari langit lalu Dia keluarkan darinya dari buah-buahan rizki bagi kalian dan Dia tundukkan bahtera untuk berlayar di laut dengan perintah-Nya dan menjadikan bagi kalian sungai-sungai. Dan menjadikan bagi kalian matahari dan bulan silih berganti dan menjadikan bagi kalian malam dan siang. Ia telah berikan bagi kalian dari segala yang kalian minta dan jika kalian menghitung nikmat Allah maka tidak akan dapat kalian hitung”(Q.S.14:32-34).

Adapun tentang keharusan manusia menjaga keseimbangan dan tidak merusaknya dan bersikap sebaik mungkin berdasarkan iman dan amal salih dengan alam dan makhluk lainnya, Allah berfirman: "Dan Jika penghuni desa beriman dan bertakwa maka akan kami bukakan untuk mereka berkat-berkat dari langit dan bumi" (Q.S.7:96).

Salah satu prinsip Islam yang penting tentang lingkungan hidup adalah perhatian yang mendalam tentang menanam pohon. Allah SWT berulangkali mengingatkan kemudahan yang telah Dia berikan kepada manusia dan menghitungnya sebagai suatu karunia:

"Dan Dialah yang menurunkan air dari langit dan lalu Kami keluarkan tumbuh-tumbuhan dari segala jenis, lalu Kami keluarkan darinya yang hijau. Dari sisi lain, berulang kali Rasulullah saw menghimbau manusia untuk hal ini: "Seorang muslim tidak menanam tanaman lalu kemudian seekor burung, manusia atau binatang memakan dari tanaman itu melainkan Allah menulis baginya sedekah"(H.R. Bukhori dan Muslim).

"Barangsiapa merawat pohon sampai tegak dan berbuah, maka setiap kali ada yang memakan dari buahnya terhitung sedekah baginya di sisi Allah" (H.R Ahmad, 4, 51, 5, 274).

Dari sisi lain, Islam menekankan pemberdayaan tanah dengan cara menanam tanaman. Untuk itu, selain pahala ukhrawi, Islam juga menent ukan balasan materiil. "Barangsiapa menghidupkan tanah, maka itu menjadi miliknya” (H.R Abu Daud, 2073).

Islam juga melarang perusakan bumi: 
"Dan janganlah kalian membuat kerusakan di muka bumi, sesudah (Allah) memperbaikinya..”(Q.S.7:56)

"Makan dan minumlah dari rizki Allah dan janganlah kalian berkeliaran di muka bumi dengan berbuat kerusakan”(Q.S.2:60)

“..dan mereka berbuat kerusakan di muka bumi dan Allah tidak menyukai orang-orang yang berbuat kerusakan”(Q.S.5:64).

Ajaran Islam menunjukkan nilai moral abadi tentang seharusnya kehormatan makhluk lain dijaga.

"Tidak seorang muslim pun yang membunuh burung gereja atau yang lain, tanpa memberikan haknya, kecuali Allah akan mempertanyakan itu darinya. Ditanya: Apa hak burung itu Ya Rasulullah? Beliau menjawab: menyembelihnya lalu memakannya dan tidak memotong kepalanya lalu membuangnya" (H.R Ahmad, 6001).

Islam juga melarang berburu binatang dan burung hanya untuk rekreasi dan hobi. Islam mengajarkan agar mengisolasi binatang yang berpenyakit menular dari binatang yang lain agar tidak menjangkiti yang lain. Dasar untuk menjaga semua jenis binatang ayat ini saja sudah mencukupi: "Ya Tuhan Kami, tiadalah Engkau menciptakan ini sia-sia, Maha Suci Engkau” (Q.S.3:191). Semua makhluk diciptakan berdasarkan tujuan dan fungsi tertentu. Oleh sebab itu, dilarang memunahkan spesies tertentu.

"Dan tiadalah binatang-binatang yang ada di bumi dan burung-burung yang terbang dengan kedua sayapnya melainkan umat-umat (juga) seperti kalian.

Tiadalah kami alpakan sesuatupun di dalam al-Kitab..." (Q.S.6:3).

Dalam riwayat lain, dari Bukhari dijelaskan bahwa seorang wanita disiksa di api neraka. Itu dikarenakan ia memenjarakan seekor kucing lalu tidak memberinya makan dan minum sampai mati. Islam melarang memotong pohon, membakar ladang dan tumbuh-tumbuhan musuh. Begitu juga menut up aliran air minum untuk musuh dan perlakuan kejam terhadap tawanan.

\section{J. Budaya Asketisme Islam dan Lingkungan Hidup}

Manusia yang menapak jalan menuju kesempurnaan material dan spiritual, tidak akan melancarkan peperangan, penghancuran dan berlaku serakah. Ia akan dapat memaksimalkan keuntungan dari karunia ilahi dari langit dan bumi. Namun, seringnya umat manusia tidak berlaku demikian sehingga terjadi banyak kerusakan di alam semesta: "Telah muncul kerusakan di darat dan laut akibat ulah manusia" (Q.S.30:41). Manusialah dengan perilakunya yang menjauh dari keseimbangan, penyebab krisis dan tercerainya ekosistem bumi. 
Mungkin para malaikat karena kawatir akan hal ini bertanya kepada Tuhan saat Dia hendak menjadikan manusia sebagai pengganti-Nya di bumi: “Apakah Engkau akan menjadikan di dalamnya yang merusak di sana dan menumpahkan darah, sementara kami bertasbih dan mensucikan-Mu' (Q.S.2: 20). Tuhan tent unya menjawab bahwa Aku mengetahui yang kalian tidak mengetahui yang berarti walaupun apa yang kalian katakan itu benar, tetapi itu bukan seluruh kebenaran. Manusia adalah makhluk yang ditiupkan ke dalamnya dari Ruh Tuhan.

Oleh sebab itulah, manusia dengan keimanan kepada Allah dan mentaati ajaran agama-Nya dapat berinteraksi secara seimbang dan harmonis dengan manusia lain, alam semesta dan ekosistem dan menjaga mereka dari kehancuran. Dengan melihat Haji, manusia dapat melihat perbaikan diri dan kesempurnaan manusia diperoleh melalui penghormatan terhadap alam. Sewaktu di miqat, manusia memegang janji ihram dan memasuki batasan-Nya, manusia tidak dapat bahkan menyakiti semut atau mencabut tumbuhan maupun semak; manusia tidak dapat merusak alam, tidak mengenakan pakaian yang penuh warna, dan lain-lain. Manusia harus menghindari segala sesuatu yang merupakan wujud sifat keegoisan dan sifat poros diri sendiri. Dalam ihram, manusia belajar cara menyampaikan pelajaran kepatuhan dan menghormati hak makhluk lain dan hak penciptanya sendiri at as seluruh hidupnya dan tidak melupakannya meskipun sejenak. Ibrahim, Nabi besar aliran monotheisme, mencapai kesempurnaan yang sesungguhnya saat dia berhasil melalui ujian ihram.

\section{K. Simpulan}

Konsep khalifah dalam Islam berakar pada transendensi ilahiah dan ḍarūriyyah insaniyyah. Konsep ini mendasari akhlak terhadap lingkungan. Kerusakan lingkungan hidup bersifat regional (seperti hujan asam) dan yang bersifat global (seperti pemanasan global, kepunahan jenis, dan kerusakan lapisan ozon di stratosfer) adalah wujud dari sirnanya transendensi ilahiyah.

Salah satu prinsip filsafat lingkungan hidup Islam adalah alam semesta diciptakan berdasarkan keseimbangan dan harmoni antar anggota alam tersebut. Konsep khalifah muncul dalam kesadaran manusia untuk berperan sebagai wakil Tuhan di muka bumi agar bertindak arif dan bijaksana dalam mengelola kekayaan alam dan bumi sehingga terhindar dari kerusakan. Untuk memperbaiki lingkungan, manusia perlu merancang teknologi ramah lingkungan. Lingkungan hidup yang ideal dapat dibangun untuk pengubahan lingkungan hidup, yakni mengurangi risiko lingkungan dan atau memperbesar 
manfaat lingkungan. Relasi manusia dalam konsep Khilafah dengan sumberdaya yang ada dalam lingkungan hidup sumberdaya lahan dan tanah, air dan udara. Allah menyebutkan secara eksplisit dalam al-Qur'an tentang petingnya lingkungan hidup dan cara-cara Islami dalam mengelola dunia ini.

\section{Daftar Pustaka}

al-Zindani, Abdul Majid bin Aziz (et al.). 1997. Mujizat Al-Qur'an dan AsSunah Tentang IPTEK. Jakarta: Gema Insani Press.

al-Qaradlawi, Yusuf. 1997. Fiqih Peradaban: Sunah Sebagai Paradigma Ilmu Pengetahuan. Jakarta: Dunia Ilmu.

[Depdikbud]. 1990. Kamus Besar Bahasa Indonesia. Jakarta: Balai Pustaka. Undang-Undang No. 4 tahun 1982.

Budihardjo, Eko. 1997. Lingkungan Binaan dan Tata Ruang Kota. Yogyakarta: Andi Offset.

http://fithab.multiply.com/journal/item/222?\&show interstitial=1\&u=\%2F journal\%2Fitem diakses pada tangga 4 Mei 2011.

Kedaulatan Rakyat. Minggu, 16 April 2000. Tahun LV Nomor 197. Hal. 8. Mitchell, Bruce, dkk. 2000. Pengelolaan Sumberdaya dan Lingkungan. Yogyakarta: Gadjah Mada University Press.

Moh. Soerjani, dkk. 1987. Lingkungan: Sumberdaya Alam dan Kependudukan dalam Pembangunan. Jakarta. UI-Press.

Pratikno, Widi Agus, dkk. 1997. Perencanaan Fasilitas Pantai dan Laut. Yogyakarta: BPFE.

Republika. Minggu, 23 April 2000. Nomor 103 Tahun Ke-8. Hal. 1.

Soemarwoto, Otto. 1997. Ekologi, Lingkungan Hidup dan Pembangunan. Jakarta: Djambatan.

1999. Visi Pembangunan IPTEK dan Lingkungan Hidup Partai Keadilan: Kesejahteraan, Kemandirian dan Kesinambungan. Jakarta: Departemen IPTEK-Lingkungan Hidup. 